\title{
MATHEMATICAL ANALYSIS OF MAXIMUM POWER GENERATED BY PHOTOVOLTAIC SYSTEMS AND FITTING CURVES FOR STANDARD TEST CONDITIONS ${ }^{1}$
}

\section{LUÍS R. A. GABRIEL FILHO ${ }^{2}$, DANIEL DOS S. VIAIS NETO ${ }^{3}$, CAMILA P. CREMASCO 4 , ODIVALDO J. SERAPHIM ${ }^{5}$, FERNANDO DE L. CANEPPELE ${ }^{6}$}

\begin{abstract}
The rural electrification is characterized by geographical dispersion of the population, low consumption, high investment by consumers and high cost. Moreover, solar radiation constitutes an inexhaustible source of energy and in its conversion into electricity photovoltaic panels are used. In this study, equations were adjusted to field conditions presented by the manufacturer for current and power of small photovoltaic systems. The mathematical analysis was performed on the photovoltaic rural system I-100 from ISOFOTON, with power $300 \mathrm{Wp}$, located at the Experimental Farm Lageado of FCA/UNESP. For the development of such equations, the circuitry of photovoltaic cells has been studied to apply iterative numerical methods for the determination of electrical parameters and possible errors in the appropriate equations in the literature to reality. Therefore, a simulation of a photovoltaic panel was proposed through mathematical equations that were adjusted according to the data of local radiation. The results have presented equations that provide real answers to the user and may assist in the design of these systems, once calculated that the maximum power limit ensures a supply of energy generated. This real sizing helps establishing the possible applications of solar energy to the rural producer and informing the real possibilities of generating electricity from the sun.
\end{abstract}

KEYWORDS: rural electrification, photovoltaic cells, numerical methods.

\section{MODELO MATEMÁTICO DA POTÊNCIA MÁXIMA GERADA POR SISTEMAS FOTOVOLTAICOS E CURVAS DE AJUSTE ÀS CONDIÇÕES DE TESTE EM CAMPO}

RESUMO: A eletrificação rural é caracterizada pela dispersão geográfica da população, baixo consumo, alto investimento por consumidor e elevado custo operacional. Por outro lado, a radiação solar constitui-se numa inesgotável fonte energética, e para sua conversão em energia elétrica são utilizados painéis fotovoltaicos. Neste trabalho, foram determinadas equações ajustadas às condições de campo apresentadas pelo fabricante para corrente e potência de sistemas fotovoltaicos de pequeno porte. A análise matemática foi feita sobre o sistema fotovoltaico rural I-100 da ISOFOTON, com potência de $300 \mathrm{Wp}$, localizado na Fazenda Experimental Lageado da FCA/UNESP. Para o desenvolvimento de tais equações, procurou-se estudar o circuito elétrico de células fotovoltaicas, aplicar os métodos numéricos iterativos para a determinação de parâmetros elétricos e analisar possíveis erros na adequação das equações existentes da literatura à realidade. Sendo assim, foi proposta a simulação de um painel fotovoltaico por meio de equações matemáticas que foram ajustadas segundo os dados de radiação locais. Os resultados apresentam equações que fornecem respostas reais para o usuário e podem auxiliar no dimensionamento destes sistemas, uma vez que a potência máxima calculada garante um limite de fornecimento da energia gerada. Este real dimensionamento auxilia a determinação das possíveis aplicações da energia solar para o produtor rural, informando as possibilidades reais de geração de energia elétrica pelo Sol.

PALAVRAS-CHAVE: eletrificação rural, células fotovoltaicas, métodos numéricos.

\footnotetext{
${ }^{1}$ Elaborado a partir da tese de doutorado do primeiro autor.

${ }^{2}$ Mestre em Matemática, Doutor e Pós-Doutor em Agronomia, Prof. Doutor, UNESP - Univ Estadual Paulista, Tupã-SP, e FCA, UNESP, Botucatu - SP, gabrielfilho@tupa.unesp.br.

${ }^{3}$ Mestre em Matemática, Prof. Associado, FATEC - Faculdade de Tecnologia de Presidente Prudente, dvneto@ fatecpp.edu.br.

${ }^{4}$ Mestre em Matemática, Doutora em Agronomia, Pós-Doutora em Biometria, Profa. Doutora, FATEC - Faculdade de Tecnologia de Presidente Prudente, e FCA/UNESP, Botucatu - SP, camila@ fatecpp.edu.br.

${ }^{5}$ Professor Adjunto III, Faculdade de Ciências Agronômicas, Botucatu - SP, seraphim@ @ca.unesp.br.

${ }^{6}$ Eng $^{\mathrm{O}}$ Eletricista, Prof. Doutor, Faculdade de Zootecnia e Engenharia de Alimentos, USP, Pirassununga - SP, caneppele@usp.br.

Recebido pelo Conselho Editorial em: 26-5-2011

Aprovado pelo Conselho Editorial em: 1ํ--3-2012
} 


\section{INTRODUCTION}

The amount of energy the sun provides the Earth is considered very large, and in just one hour, energy, which is consumed by humanity during a year, reaches our planet. As the sun is a free renewable energy source and does not pollute the environment, the use of its energy for electricity supply represents a viable alternative, particularly where access to conventional electricity is difficult or uneconomic (MACIEL et al., 2008).

In this sense, global environmental concerns and growing demand for energy, along with the steady progress in renewable energy technologies are opening new opportunities for the use of renewable energy resources. The solar energy is the most abundant, inexhaustible and clean of all renewable energy resources until this date. The power of the sun intercepted by the Earth is about $1.8 \times 1011 \mathrm{MW}$, which is much bigger than the current rate of all energy consumption (PARIDA et al., 2011).

According to MARINI \& ROSSI (2005), the energy supply to isolated rural communities and remote areas has been a constant challenge, especially in underdeveloped or developing countries, due to the enormous economic and social disparities, and often the geographical dimensions of these countries. In agricultural engineering, mathematical models with real application in the area are being developed by using correction equations of numerical temporal variables (GABRIEL FILHO et al., 2011), whether by developing systems based on artificial intelligence (GABRIEL FILHO et al., 2011 be PEREIRA et al., 2008), and analytical equations for the optimization of photovoltaic systems (GABRIEL FILHO et al., 2011).

Small farms in Brazil, particularly those located in rural homes, according to their characteristic location often in remote areas of the distribution networks of conventional electricity, plus the fact that it has a low demand, do not justify, in most cases, the investment network extension: in this context, they present a suitable space for the application of the photovoltaic power generation, which provide a local solution as a renewable and reliable energy source and it can promote the self-sustainable social and economic development of rural populations, improving the quality of life of its inhabitants (FRAGA, 2009).

Excluding the manufacturing process of the modules, according ALVES \& CAGNON (2010), another important factor in expanding the use of photovoltaic technology is the environmental appeal, because these systems are characterized not to change the thermal balance of the earth, operating without the need of greenhouse gases or acid gases for the formation of lakes reservoirs and the deforestation only occurs in large installations, which are often built in semi-arid or desert areas.

According to CASTRO (2008), photovoltaic cells (Figure 1) comprise a semiconductor material - silicon - which is added substances, named doping to create a suitable means for establishing the photovoltaic effect, i.e. direct conversion of power linked to the solar radiation into DC electrical power. Furthermore, CASTRO (2008) states that the cell is the smallest element of the photovoltaic system, producing electrical power typically of the order of $1.5 \mathrm{Wp}$ (corresponding to a voltage of $0.5 \mathrm{~V}$ and a current of $3 \mathrm{~A}$ ).

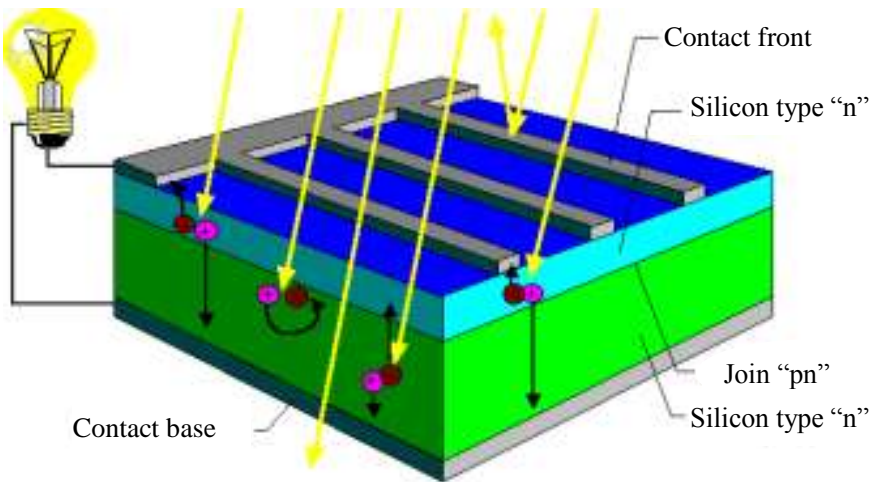

FIGURE 1. Internal constitution of a typical photovoltaic cell (CRESESB/CEPEL, 2009). 
According to FRAGA (2009), photovoltaic module (Figure 2) is the basic unit of the entire system. The module is composed of solar cells connected in arrangements producing sufficient voltage and current for energy use. The number of cells connected in a module and their arrangement, which can be set and/or parallel, depends on the operating voltage and electric current desired. Once having the desired configuration, the assembly is encapsulated with special material that protects it from possible external damage.

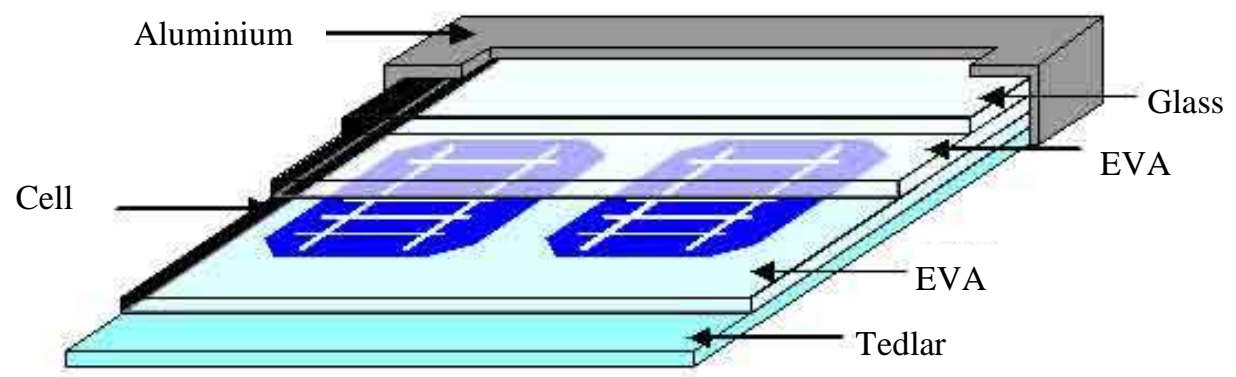

FIGURE 2. Photovoltaic module. (CBSOLAR, online, 2011).

Photovoltaic modules are also possible in the cluster so that the available power is adequate for the intended application. These panels associated with other devices that transform or store electrical energy so that it can be used, is called the photovoltaic system.

Applications of electricity generated by PV systems are small, as the system used in this study are generally very useful for farmers. The energy produced by these systems may be used among other ways to: pump water for human consumption, animals and small irrigation systems, operate electric motors of lower power, lighting, telephony, etc. These services are generally of great importance for the farmer, therefore equations of such systems for an adequate sizing of use is required.

The equations governing the operation of PV systems generally refer to some difference in the results of field measurements, possibly due to the fact of the theoretical approaches already has in its conception or may not contain the details of the module manufacturing equipment, or due to local environmental factors.

There are studies (CELIK \& ACIKGOZ, 2007) searching for means of electrical parameters to compare the results of modeling and experimental verification, indicating which option best fits the model to the actual operating conditions.

However, an appropriate model to the actual operating conditions without the need for testing parameters combinations would be of fundamental importance for the correct use of an analytical model / mathematical models for PV.

The objective of this study is to determine the analytical forms of the curves of current and photovoltaic power, and calculate the points of power, voltage and maximum current, as well as create a mathematical model to field conditions related to the PV system located in the Experimental Farm Lageado of FCA/UNESP.

\section{MATERIAL AND METHODS}

\section{Materials}

The photovoltaic system used in this work has been installed at the Laboratory of Rural Power of the Engineering Department of UNESP, Faculdade de Ciências Agronômicas, Lageado, located in Botucatu, State of São Paulo.

For the PV system formation, concerning the generation of electricity from solar energy incident on the site, it was used three single-crystalline silicon photovoltaic modules of the I-100 Isofoton with nominal power of $100 \mathrm{Wp}$ each (a total of $300 \mathrm{Wp}$ installed ), the technical task of 
cells 36 in series, two cells in parallel, $0.72 \mathrm{~m}^{2}$ of cells, and TONC $\left(800 \mathrm{Wm}^{-2}, 20^{\circ} \mathrm{C}, \mathrm{AM} 1.5\right.$, $1 \mathrm{~ms}^{-1}$ ) $47^{\circ} \mathrm{C}$ (Figure 3 and Table 1). The data supplied by the manufacturer of the panels for simulating the analytical models / preparation of curves developed and also to compare the results of the equations are given in Table 1.

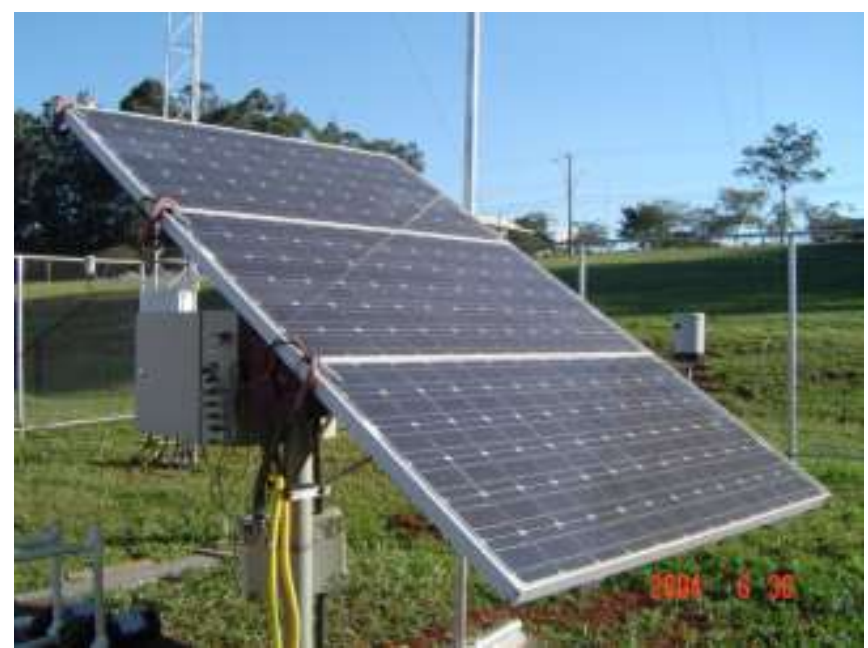

FIGURE 3. PV modules of $100 \mathrm{Wp}$ each, installed in parallel and constituting the photovoltaic panel system installed at the Laboratory of Rural Energization of FCA/UNESP.

TABLE 1. Electrical specifications of photovoltaic modules in operating condition $1000 \mathrm{~W} \mathrm{~m}^{-2}$, $25^{\circ} \mathrm{C}$ cell and PM 1.5.

\begin{tabular}{ll}
\hline Maximum Power $\left(P_{\max }\right)$ & $100 \mathrm{Wp} \pm 10 \%$ \\
\hline Short-circuit current $\left(I_{s c}\right)$ & $6.54 \mathrm{~A}$ \\
\hline Open circuit voltage $\left(V_{o c}\right)$ & $21.6 \mathrm{~V}$ \\
\hline Maximum Power current $\left(I_{\max }\right)$ & $5.74 \mathrm{~A}$ \\
\hline Maximum Power tension $\left(V_{\max }\right)$ & $17.4 \mathrm{~V}$ \\
\hline
\end{tabular}

\section{Methods}

The methodology of this study was developed in accordance to the proposed objectives, concerned with the development of deterministic mathematical models and obtaining practical results via numerical methods.

To develop governing equations of the strength of the photovoltaic systems, the circuitry of photovoltaic cells was studied, according to CASTRO (2008), it can be described according to Figure 4 , where it can be seen the series resistance $R_{s}[\Omega]$, representing the voltage drop in circuit to the external contacts, and the parallel resistance $R_{p}[\Omega]$, representing the leakage current.

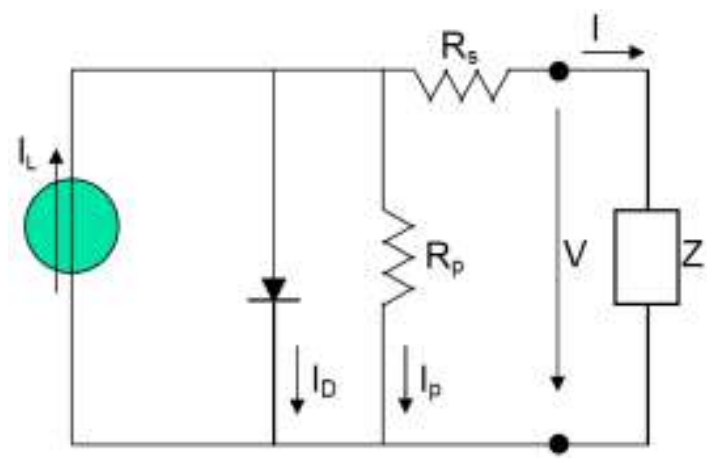

FIGURE 4. Detailed electrical equivalent circuit of a solar cell powering a Z load. (CASTRO, 2008). 
The current lighting (or photogerated) $I_{L}$ resulting from the loads generated by the illumination of the material represents the electric current generated by the beam of light radiation consisting of photons reaching the active surface of the cell (photovoltaic effect). This unidirectional current is constant for a given incident radiation. The p-n junction acts as a diode which is traversed by an inward-way $I_{D}$ which depends on the voltage $V$ at the terminals of the cell. According to LORENZO (1994), the relationship between current and voltage $V$ in the photovoltaic cell, passing through the load, is given by

$$
\mathrm{I}=\mathrm{I}_{\mathrm{L}}-\mathrm{I}_{\mathrm{D}}-\mathrm{I}_{\mathrm{P}}
$$

or

$$
\mathrm{I}=\mathrm{I}_{\mathrm{L}}-\mathrm{I}_{\mathrm{O}}\left(\exp \frac{\mathrm{V}+\mathrm{IR}_{\mathrm{S}}}{\mathrm{V}_{\mathrm{t}}}-1\right)-\frac{\mathrm{V}+\mathrm{IR}_{\mathrm{S}}}{\mathrm{R}_{\mathrm{P}}}
$$

In which:

$$
\begin{aligned}
& I_{D}=I_{o}\left(\exp \frac{V+I_{s}}{V_{t}}\right) \text { - current that goes through diode, A; } \\
& \mathrm{I}_{\mathrm{O}} \text { - dark current, A; } \\
& \mathrm{V}_{\mathrm{t}}=\frac{\mathrm{mkT}_{\mathrm{c}}}{\mathrm{q}}-\text { thermal voltage, } \mathrm{V} \text {; } \\
& \mathrm{m} \text { - diode ideality factor, dimensionless; } \\
& \mathrm{k}=1.3810^{-23} \text { - Boltzmann constant, } \mathrm{J} \mathrm{K}^{-1} \text {; } \\
& \mathrm{T}_{\mathrm{c}} \text { - temperature of the PV cell, } \mathrm{K} \text {; } \\
& q=1.610^{-19} \text { - electron charge, } C \text {, and } \\
& I_{p}=\frac{V+I R_{s}}{R_{p}}-\text { represents the leakage currents, A. }
\end{aligned}
$$

Equation (2) can appropriately represent the operation of a solar cell, but it has some inconveniences in practical use. The term has an implicit character; the current appears on both sides of the equation, forcing its resolution by iterative methods. Furthermore, the parameters, $I_{L}$, $I_{o}, R_{s}$ and $R_{p}$ are difficult to determine.

For the application of numerical methods is required operating parameters of the modules provided by the manufacturer measured in conditions called Standard Conditions (STC - Standard Test Conditions) or referred to herein by Field Test Conditions, defined by the irradiance of $1000 \mathrm{~W} \mathrm{~m}^{-2}$ (solar radiation received at the Earth's surface in daylight, at noon), $25{ }^{\circ} \mathrm{C}$ in the cell (cell efficiency is reduced with increasing temperature), the wind speed of $1 \mathrm{~m} \mathrm{~s}^{-1}$ and spectral distribution (BF) 1.5 .

The numerical method (iterative) used was Newton's method (ARENALES \& DAREZZO, 2008), which consists in the estimation of the roots of a function. For its application, it becomes initially, as shown in Figure 5, a point $x_{0}$ in the field of function possibly close to the solution $r_{1}$, and calculates the intercept of the tangent line to the function at that point with the $\mathrm{x}$-axis whose abscissa is denoted by $x_{1}$. If $f\left(x_{1}\right)$ is near zero, the point $x_{1}$ is elected as the solution (root) of the equation. Otherwise, the process $x_{1}$ is repeated until $f\left(x_{i}\right)$ is sufficient to almost zero, thus establishing the convergence of the process. If there is no convergence, or elects another value for the initial condition $x_{0}$, or should look for another iterative method. In mathematical notation, this process can be written as follows: 


$$
x_{n+1}=x_{n}-\frac{f\left(x_{n}\right)}{f^{\prime}\left(x_{n}\right)}
$$

Where in $n$ indicates the nth algorithm interaction and $f^{\prime}\left(x_{n}\right)$ is the derivate function $f$ in $x_{n}$.

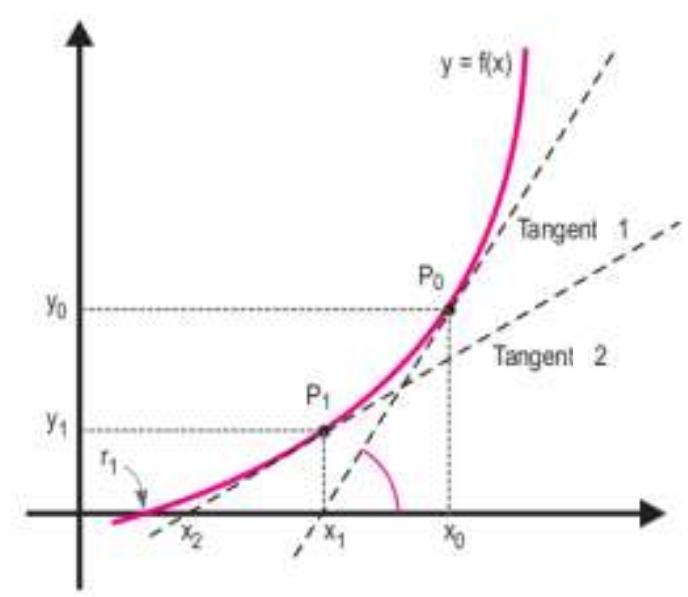

FIGURE 5. Newton's method (adapted from ARENALES \& DAREZZO, 2008).

Thus, the application of numerical methods to the conditions STC, it is possible to obtain the points of maximum power $\left(P_{\max }\right)$, and also the current $\left(I_{\max }\right)$ and voltage $\left(V_{\max }\right)$ that produce such power, in which $P_{\max }=I_{\max } \cdot V_{\max }$. Because these numerical values having certain error when compared to the Field Test conditions, curves were obtained from the equations of the PV system adjusted to these conditions using analytical methods.

\section{RESULTS AND DISCUSSION}

\section{Theoretical results}

According to LORENZO (1994), the effect of parallel resistance is negligible, then we can consider $I_{p}=0$. The generated current and short circuit are equal, i.e. $I_{L}=I_{s c}$. Thus, $\left(\exp \frac{\mathrm{V}+\mathrm{IR}_{\mathrm{s}}}{\mathrm{V}_{\mathrm{t}}}\right)>1$ in any work conditions, and $\left(\exp \frac{\mathrm{V}+\mathrm{IR}_{\mathrm{s}}}{\mathrm{V}_{\mathrm{t}}}\right)>>1$. Therefore, the current $(I)$ may be shown by means of:

$$
\mathrm{I}=\mathrm{I}_{\mathrm{sc}}\left[1-\exp \left(\frac{\mathrm{V}-\mathrm{V}_{\mathrm{oc}}+\mathrm{I}_{\mathrm{sc}} \mathrm{R}_{\mathrm{s}}}{\mathrm{V}_{\mathrm{t}}}\right)\right]
$$

In which $V_{O C}$ is the open circuit tension. As $P=V I$, so the Power $(P)$ in the PV cell is given by:

$$
\mathrm{P}=\mathrm{VI}_{\mathrm{sc}}\left[1-\exp \left(\frac{\mathrm{V}-\mathrm{V}_{\mathrm{oc}}+\mathrm{I}_{\mathrm{sc}} \mathrm{R}_{\mathrm{s}}}{\mathrm{V}_{\mathrm{t}}}\right)\right]
$$

The theorems below show ways of obtaining the series resistance and the maximum power of a solar cell that these results can be extended to modules by laws in series and parallel association.

Theorem 1: The series resistance of solar photovoltaic cell is given by: 


$$
\mathrm{R}_{\mathrm{s}}=\frac{-\mathrm{V}+\mathrm{V}_{\mathrm{oc}}+\mathrm{V}_{\mathrm{t}} \ln \left(1-\frac{\mathrm{I}}{\mathrm{I}_{\mathrm{sc}}}\right)}{\mathrm{I}_{\mathrm{sc}}}
$$

\section{Demonstration:}

By eq.(4), is given:

$$
\begin{aligned}
& \mathrm{I}=\mathrm{I}_{\mathrm{sc}}\left[1-\exp \left(\frac{\mathrm{V}-\mathrm{V}_{\mathrm{oc}}+\mathrm{I}_{\mathrm{sc}} \mathrm{R}_{\mathrm{s}}}{\mathrm{V}_{\mathrm{t}}}\right)\right] \Rightarrow 1-\frac{\mathrm{I}}{\mathrm{I}_{\mathrm{sc}}}=\exp \left(\frac{\mathrm{V}-\mathrm{V}_{\mathrm{oc}}+\mathrm{I}_{\mathrm{sc}} \mathrm{R}_{\mathrm{s}}}{\mathrm{V}_{\mathrm{t}}}\right) \\
& \Rightarrow \ln \left(1-\frac{\mathrm{I}}{\mathrm{I}_{\mathrm{sc}}}\right)=\frac{\mathrm{V}-\mathrm{V}_{\mathrm{oc}}+\mathrm{I}_{\mathrm{sc}} \mathrm{R}_{\mathrm{s}}}{\mathrm{V}_{\mathrm{t}}} \Rightarrow \mathrm{R}_{\mathrm{s}}=\frac{-\mathrm{V}+\mathrm{V}_{\mathrm{oc}}+\mathrm{V}_{\mathrm{t}} \ln \left(1-\frac{\mathrm{I}}{\mathrm{I}_{\mathrm{sc}}}\right)}{\mathrm{I}_{\mathrm{sc}}},
\end{aligned}
$$

concluding the demonstration.

In the next theorem, we present an equation involving the maximum power for photovoltaic cells. This equation can be extended to modules and photovoltaic generators according to GABRIEL FILHO (2007).

Theorem 2: The maximum power $\left(P_{\max }\right)$ of a photovoltaic cell, and also the voltage $\left(V_{\max }\right)$ and current $\left(I_{\max }\right)$ in the cell that produce such power is given by:

$$
\begin{aligned}
& \mathrm{P}_{\text {max }}=\mathrm{V}_{\text {max }} \mathrm{I}_{\mathrm{sc}}\left[1-\exp \left(\frac{\mathrm{V}_{\text {max }}-\mathrm{V}_{\mathrm{oc}}+\mathrm{I}_{\mathrm{sc}} \mathrm{R}_{\mathrm{s}}}{\mathrm{V}_{\mathrm{t}}}\right)\right] \\
& \mathrm{V}_{\text {max }}=\mathrm{V}_{\mathrm{oc}}-\mathrm{I}_{\mathrm{sc}} \mathrm{R}_{\mathrm{s}}-\mathrm{V}_{\mathrm{t}} \ln \left(1+\frac{\mathrm{V}_{\text {max }}}{\mathrm{V}_{\mathrm{t}}}\right)
\end{aligned}
$$

and

$$
I_{\max }=I_{s c}\left[1-\exp \left(\frac{V_{\max }-V_{o c}+I_{s c} R_{s}}{V_{t}}\right)\right]
$$

\section{Demonstration:}

As $\mathrm{P}=\mathrm{V} \mathrm{I}_{\mathrm{sc}}\left[1-\exp \left(\frac{\mathrm{V}-\mathrm{V}_{\mathrm{oc}}+\mathrm{I}_{\mathrm{sc}} \mathrm{R}_{\mathrm{s}}}{\mathrm{V}_{\mathrm{t}}}\right)\right]$, then: 


$$
\begin{aligned}
& \frac{\mathrm{dP}}{\mathrm{dV}}=\frac{\mathrm{d}\left[\mathrm{V} \mathrm{I}_{\mathrm{sc}}\left[1-\exp \left(\frac{\mathrm{V}-\mathrm{V}_{\mathrm{oc}}+\mathrm{I}_{\mathrm{sc}} \mathrm{R}_{\mathrm{s}}}{\mathrm{V}_{\mathrm{t}}}\right)\right]\right]}{\mathrm{dV}}= \\
& =I_{s c}\left[1-\exp \left(\frac{\mathrm{V}-\mathrm{V}_{\mathrm{oc}}+\mathrm{I}_{\mathrm{sc}} \mathrm{R}_{\mathrm{s}}}{\mathrm{V}_{\mathrm{t}}}\right)\right]+\mathrm{V} \frac{\mathrm{d}\left[\mathrm{I} \mathrm{sc}\left[1-\exp \left(\frac{\mathrm{V}-\mathrm{V}_{\mathrm{oc}}+\mathrm{I}_{\mathrm{sc}} \mathrm{R}_{\mathrm{s}}}{\mathrm{V}_{\mathrm{t}}}\right)\right]\right]}{\mathrm{dV}} \\
& =I_{s c}\left[1-\exp \left(\frac{V-V_{o c}+I_{s c} R_{s}}{V_{t}}\right)\right]-\frac{V_{s c}}{V_{t}}\left[\exp \left(\frac{V-V_{o c}+I_{s c} R_{s}}{V_{t}}\right)\right] \frac{d\left(V-V_{o c}+I_{s c} R_{s}\right)}{d V}= \\
& =I_{s c}\left[1-\exp \left(\frac{\mathrm{V}-\mathrm{V}_{\mathrm{oc}}+\mathrm{I}_{\mathrm{sc}} \mathrm{R}_{\mathrm{s}}}{\mathrm{V}_{\mathrm{t}}}\right)\right]-\left(\frac{\mathrm{V}_{\mathrm{sc}}}{\mathrm{V}_{\mathrm{t}}}\right) \exp \left(\frac{\mathrm{V}-\mathrm{V}_{\mathrm{oc}}+\mathrm{I}_{\mathrm{sc}} \mathrm{R}_{\mathrm{s}}}{\mathrm{V}_{\mathrm{t}}}\right)= \\
& =\mathrm{I}_{\mathrm{sc}}\left[1-\left(1+\frac{\mathrm{V}}{\mathrm{V}_{\mathrm{t}}}\right) \exp \left(\frac{\mathrm{V}-\mathrm{V}_{\mathrm{oc}}+\mathrm{I}_{\mathrm{sc}} \mathrm{R}_{\mathrm{s}}}{\mathrm{V}_{\mathrm{t}}}\right)\right] \Rightarrow \frac{\mathrm{dP}}{\mathrm{dV}}=\mathrm{I}_{\mathrm{sc}}\left[1-\left(1+\frac{\mathrm{V}}{\mathrm{V}_{\mathrm{t}}}\right) \exp \left(\frac{\mathrm{V}-\mathrm{V}_{\mathrm{oc}}+\mathrm{I}_{\mathrm{sc}} \mathrm{R}_{\mathrm{s}}}{\mathrm{V}_{\mathrm{t}}}\right)\right]
\end{aligned}
$$

The maximum power point $P_{\max }$ may be determined by doing $\frac{d P}{d V}=0$. Therefore,

$$
\begin{aligned}
& \frac{\mathrm{dP}}{\mathrm{dV}}=0 \Rightarrow \mathrm{I}_{\mathrm{sc}}\left[1-\left(1+\frac{\mathrm{V}}{\mathrm{V}_{\mathrm{t}}}\right) \exp \left(\frac{\mathrm{V}-\mathrm{V}_{\mathrm{oc}}+\mathrm{I}_{\mathrm{sc}} \mathrm{R}_{\mathrm{s}}}{\mathrm{V}_{\mathrm{t}}}\right)\right]=0 \\
& \Rightarrow\left(1+\frac{\mathrm{V}}{\mathrm{V}_{\mathrm{t}}}\right) \exp \left(\frac{\mathrm{V}-\mathrm{V}_{\mathrm{oc}}+\mathrm{I}_{\mathrm{sc}} \mathrm{R}_{\mathrm{s}}}{\mathrm{V}_{\mathrm{t}}}\right)=1 \Rightarrow \exp \left(\frac{\mathrm{V}-\mathrm{V}_{\mathrm{oc}}+\mathrm{I}_{\mathrm{sc}} \mathrm{R}_{\mathrm{s}}}{\mathrm{V}_{\mathrm{t}}}\right)=\left(1+\frac{\mathrm{V}}{\mathrm{V}_{\mathrm{t}}}\right)^{-1} \\
& \Rightarrow \frac{\mathrm{V}-\mathrm{V}_{\mathrm{oc}}+\mathrm{I}_{\mathrm{sc}} \mathrm{R}_{\mathrm{s}}}{\mathrm{V}_{\mathrm{t}}}=\ln \left(1+\frac{\mathrm{V}}{\mathrm{V}_{\mathrm{t}}}\right)^{-1} \Rightarrow \frac{\mathrm{V}-\mathrm{V}_{\mathrm{oc}}+\mathrm{I}_{\mathrm{sc}} \mathrm{R}_{\mathrm{s}}}{\mathrm{V}_{\mathrm{t}}}=-\ln \left(1+\frac{\mathrm{V}}{\mathrm{V}_{\mathrm{t}}}\right) \\
& \Rightarrow \mathrm{V}-\mathrm{V}_{\mathrm{oc}}+\mathrm{I}_{\mathrm{sc}} \mathrm{R}_{\mathrm{s}}=-\mathrm{V}_{\mathrm{t}} \ln \left(1+\frac{\mathrm{V}}{\mathrm{V}_{\mathrm{t}}}\right) \Rightarrow \mathrm{V}=\mathrm{V}_{\mathrm{oc}}-\mathrm{I}_{\mathrm{sc}} \mathrm{R}_{\mathrm{s}}-\mathrm{V}_{\mathrm{t}} \ln \left(1+\frac{\mathrm{V}}{\mathrm{V}_{\mathrm{t}}}\right)
\end{aligned}
$$

Therefore, the maximum power point occurs when $V=V_{o c}-I_{s c} R_{s}-V_{t} \ln \left(1+\frac{V}{V_{t}}\right)$.

This implies that $V_{\max }=V_{o c}-I_{s c} R_{s}-V_{t} \ln \left(1+\frac{V_{\max }}{V_{t}}\right)$. The demonstration of (7) and (9) follows (4) and (5).

\section{Practical results}

It is necessary to determine some characteristic values of the photovoltaic system in relation to the photovoltaic cell, the photovoltaic module and solar generator used. The generator consists of 3 modules in parallel $\left(N_{p m}=3\right)$, absence of modules connected in series $\left(N_{s m}=1\right)$. The association of the cells of the PV system was made with module of 72 cells, grouped in the form of 36 series cell $\left(N_{s c}=36\right)$ and 2 parallel cell $\left(N_{p c}=2\right)$. 
In accordance to the technical specifications of photovoltaic modules provided by manufacturers in Table 1, it was obtained the data of Table 2.

TABLE 2. Characteristic values of the photovoltaic module provided by the manufacturer in standard operating condition. (GABRIEL FILHO, 2007 e GABRIEL FILHO et al., 2010).

\begin{tabular}{lcc}
\hline \multicolumn{1}{c}{ Characteristic Values } & Cell & Module \\
\hline Active Area $\left(A_{a}\right),\left[\mathrm{m}^{2}\right]$ & - & 0.72 \\
\hline Open Circuit Tension $\left(V_{o c}\right),[\mathrm{V}]$ & - & 21.6 \\
\hline Short Circuit Current $\left(I_{s c}\right),[\mathrm{A}]$ & - & 6.54 \\
\hline Maximum Power Tension $\left(V_{\max }\right),[\mathrm{V}]$ & - & 17.4 \\
\hline Maximum Power Current $\left(I_{\max }\right),[\mathrm{A}]$ & - & 5.74 \\
\hline Maximum Power $\left(P_{\max }\right),[\mathrm{w}]$ & - & 100 \\
\hline Series Resistence $\left(R_{s}\right),[\Omega]$ & - & - \\
\hline Thermal Tension $\left(V_{t}\right),[\mathrm{V}]$ & - & - \\
\hline
\end{tabular}

The data for the photovoltaic cell shown in Table 2, can be calculated through the laws of associations in series and parallel resistors with voltage and current associated (Table 3), except parameters and Voltage Thermal Resistance Series. These parameters are then calculated for the photovoltaic cell, and later obtained the values equivalent to the modules through associations with such laws.

In field testing conditions, the cell temperature is $25^{\circ} \mathrm{C}$ and thus $\mathrm{T}_{\mathrm{c}}=(273.16+25)$ $\mathrm{K}=298.16 \mathrm{~K}$. Observing that the Boltzmann constant is given by $\mathrm{k}=1.380650510^{-23} \mathrm{~J} \mathrm{~K}^{-1}$ the electron charge $e=1.60205 .10^{-19} \mathrm{C}$ and it is given the diode ideality factor as (the optimum condition), it was calculated, respectively, the thermal voltage of the solar cell, and the generator module as follows:

$$
\mathrm{V}_{\mathrm{tc}}=\frac{\mathrm{mkT}_{\mathrm{c}}}{\mathrm{e}}=\frac{1\left(1.380650510^{-23}\right) 298.16}{1.6020510^{-19}}=0.0256955
$$

By theorem 1 is given:

$$
\mathrm{R}_{\mathrm{sc}}=\frac{-0.48333333+0.6+0.0256955 \ln \left(1-\frac{2.87}{3.27}\right)}{3.27}=0.0191677
$$

TABLE 3. Characteristic values of a cell, module and photovoltaic generator on the Field Test Conditions obtained from the manufacturer's information.

\begin{tabular}{lcc}
\hline \multicolumn{1}{c}{ Characteristic values } & Cell & Module \\
\hline Active Area $\left(A_{a}\right),\left[\mathrm{m}^{2}\right]$ & 0.01 & 0.72 \\
\hline Open Circuit Tension $\left(V_{o c}\right),[\mathrm{V}]$ & 0.6 & 21.6 \\
\hline Short Circuit Current $\left(I_{s c}\right),[\mathrm{A}]$ & 3.27 & 6.54 \\
\hline Maximum Power Tension $\left(V_{\max }\right),[\mathrm{V}]$ & 0.483 & 17.4 \\
\hline Maximum Power Current $\left(I_{\max }\right),[\mathrm{A}]$ & 2.87 & 5.74 \\
\hline Maximum Power $\left(P_{\max }\right),[\mathrm{w}]$ & 1.389 & 100 \\
\hline Series Resistence $\left(R_{s}\right),[\Omega]$ & 0.0192 & 0.345 \\
\hline Thermal Tension $\left(V_{t}\right),[\mathrm{V}]$ & 0.0257 & 0.925 \\
\hline
\end{tabular}


To determine the error between the data from Field Test Conditions (Table 3) and those obtained by the mathematical models, the maximum power points of photovoltaic solar cell will be determined through of Theorem 2. Using the values $R_{s}$ and $V_{t}$ presented in Table 3, and also some data provided by the manufacturer, it was possible to apply Newton's method to obtain the value $V_{\max }$ of the following equation:

$$
\mathrm{V}_{\text {max }}-\mathrm{V}_{\mathrm{oc}}+\mathrm{I}_{\mathrm{sc}} \mathrm{R}_{\mathrm{s}}+\mathrm{V}_{\mathrm{t}} \ln \left(1+\frac{\mathrm{V}_{\max }}{\mathrm{V}_{\mathrm{t}}}\right)=0
$$

in which it is considered $f(x)$ equal to the first member (12), $x=V_{\max }$ and $x_{0}=0.4$ obtaining the maximum voltage value to the cell $V_{\max c}=0.461705$, according to Table 4 .

TABLE 4. Results of the Newton's Method.

\begin{tabular}{cccccc}
\hline $\boldsymbol{n}$ & $\boldsymbol{x}_{\boldsymbol{n}}$ & $\boldsymbol{f}\left(\boldsymbol{x}_{\boldsymbol{n}}\right)$ & $\boldsymbol{f}^{\prime}\left(\boldsymbol{x}_{\boldsymbol{n}}\right)$ & $\boldsymbol{x}_{\boldsymbol{n}+\boldsymbol{I}}$ & Error Estimation \\
\hline 0 & 0.4 & -0.06518386 & 1.06036122 & 0.46147325704 & 0.133210876 \\
\hline 1 & 0.461473257044 & -0.00024463 & 1.05274456 & 0.46170563088 & 0.000503294 \\
\hline 2 & 0.461705630889 & $-2.9222 \mathrm{E}-09$ & 1.05271941 & 0.46170563366 & 0.000000006 \\
\hline 3 & 0.461705633665 & 0 & 1.05271941 & 0.46170563366 & 0 \\
\hline
\end{tabular}

By Theorem 1 and in accordance to the laws in series and parallel associations of resistances with associated voltage and current, it is defined $I_{\max c}=3.0976$ and $P_{\max c}=1.4302$.

By eqs.(4) and (5) and to the values listed in Table 3 for the standard conditions of operation of each photovoltaic cell module under consideration, it is possible to obtain the characteristic curve and the power curve for the cell (Figure 6). The characteristic curve and the power curve for the photovoltaic cell that currently exist in the model are given by:

$$
\mathrm{I}=327\left[1-\exp \left(\frac{\mathrm{V}-0.5373}{0.0256955}\right)\right] \text { e } \mathrm{P}=3.27 \mathrm{~V}\left[1-\exp \left(\frac{\mathrm{V}-0.5373}{0.0256955}\right)\right]
$$

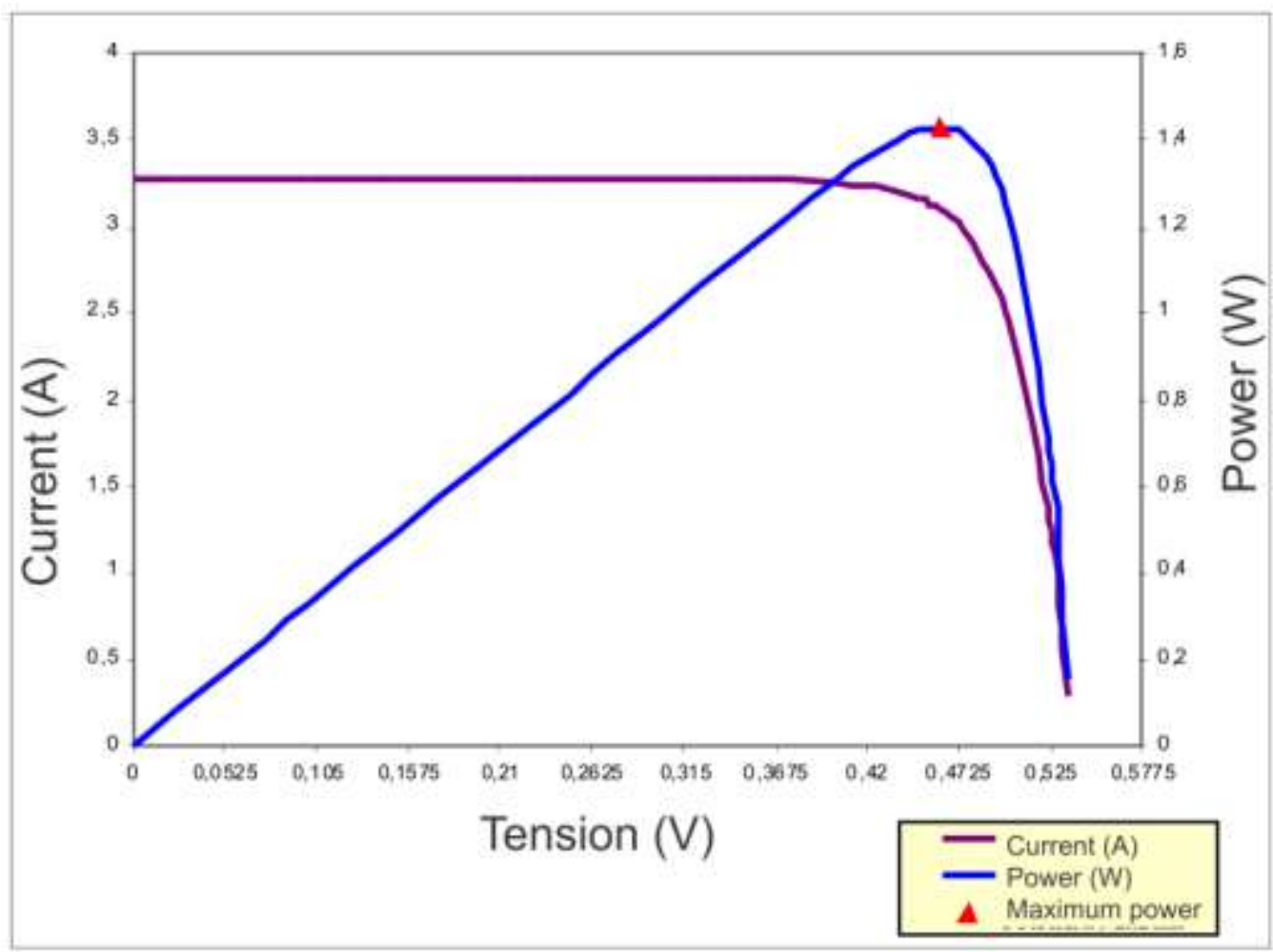

FIGURE 6. Current and power curves of the photovoltaic solar cell according to the STC tension conditions by developed equations. 
The above figures are approximations of the values provided by the manufacturer under the conditions STC, whose comparisons are given in Table 5 also using information in Table 2.

TABLE 5. Comparisons of characteristic values at points of maximum power of the photovoltaic cell in the STC.

\begin{tabular}{lccc}
\hline \multicolumn{1}{c}{ Cell Characteristic Values } & Specified by manufacturer & Mathematical Model & Error \\
\hline Maximum Power Tension & 0.48333333 & 0.461705 & $-4.47 \%$ \\
\hline Maximum Power Current & 2.87 & 3.0976 & $7.93 \%$ \\
\hline Maximum Power & 1.3888889 & 1.4302 & $2.97 \%$ \\
\hline
\end{tabular}

In Table 5, we can see different values in quantities specified by the manufacturer and the values calculated using the mathematical model, with respective errors between them in STC conditions. Such differences are not due to numerical model applied as in Table 4, the error was null and not assigned to the observations performed under standard conditions by the manufacturer, compared to tests performed in laboratories.

The errors are due to analytical procedures used in the model described because the equations in the literature that have been used for the development of theorems hypotheses have already demonstrated that they do not consider certain electrical phenomena. This can be featured in eq.(4), which is a simplification of eq.(2) even with the setting of one of its variables, and also in eq.(10), which is considered as the optimum condition for the ideality factor LED $(m=1)$, which does not always occur under field conditions.

Thus, it can be assumed that all possible values being obtained by the proposed calculation will always have an error. Therefore, it is necessary when creating graphics for current and power to consider this approximation error for the adequacy of existing equations from literature to reality.

Shortly, it will be seen that the highest values for any possible errors of $P, V$ and $I$, are observed errors (Table 5) to the maximum power point $\left(P_{\max }\right)$, and voltage $\left(V_{\max }\right)$ and current $\left(I_{\max }\right)$ that produce such power. For adaptation to Field Test Conditions (STC) is then established by Table 5 that the errors in the data provided by the manufacturer of voltage, current and power are $-4.47 \%, 7.93 \%$ and $2.97 \%$, respectively. Thus, the variables $V^{*}, I^{*}$ and $P^{*}$ are created such magnitudes in field test conditions and therefore have $V=0.9553 . V^{*}, I=1.0793 . I^{*}$ and $P=P^{*} / 1.0297$. Substituting these values in equations (13), have new equations for current and Power:

$$
\mathrm{I}^{*}=3.03\left[1-\exp \left(\frac{0.9553 \mathrm{~V} *-0.5373}{0.0256955}\right)\right] \text { e } \mathrm{P}^{*}=3.03 \mathrm{~V} *\left[1-\exp \left(\frac{0.9553 \mathrm{~V}^{*}-0.5373}{0.0256955}\right)\right]
$$

Figure 7 shows a comparison between the current and power curves of the photovoltaic cell voltage as a function of standard operating conditions using eq.(13) developed in this study by eq.(14) adjusted on the Field Test Conditions supplied by the manufacturer. 


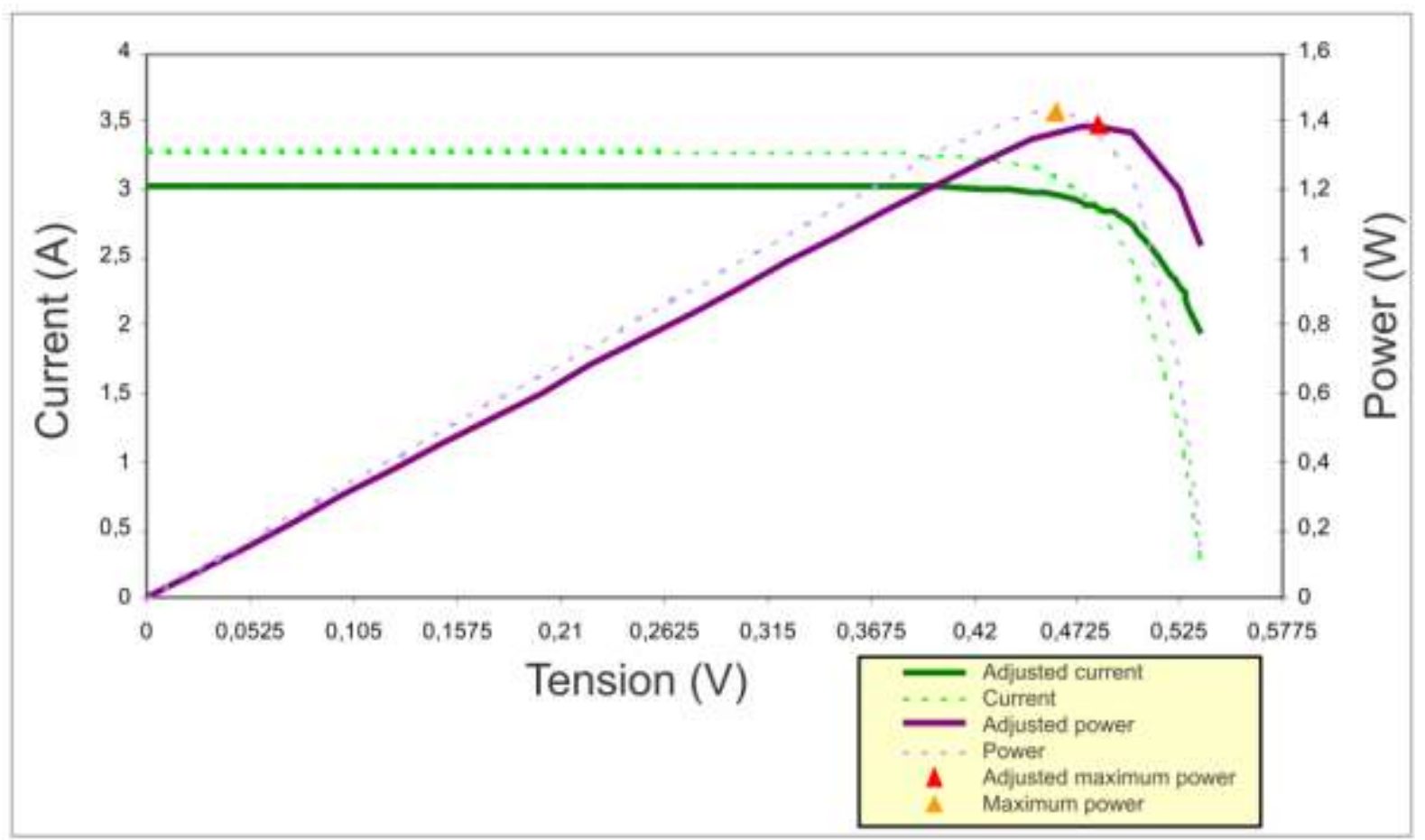

FIGURE 7. Comparison between the current and power curves of the photovoltaic solar cell and adjusted curves of to field conditions provided by the manufacturer.

\section{CONCLUSIONS}

This study presented a methodology for the determination of curves and points of occurrence of maximum power. The scientific contribution of the methods examined is the adequacy of mathematical models for real results concerning the Field Test Condition.

Thus, the curves created from this study provide real answers for the user. The methods and theorems of the photovoltaic systems showed may be helpful for the further sizing applications of these systems, since the maximum power limit calculated ensures a supply of power output.

Moreover, this methodology is a tool to enable analysis of the scaling in real situations established by the manufacturer, helping to determine the potential applications of solar energy for rural producers, informing the real possibilities of generating electricity from the sun.

\section{ACKNOWLEDMENTS}

The authors thank the Graduate Program in Agronomy FCA/UNESP/ Botucatu supported by scientific and structural availability, Prope - Dean of Research at UNESP, for the financial support which enabled this publication and also to the anonymous collaborators, whose comments and suggestions contributed to important improvements for this study.

\section{REFERENCES}

ALVES, A.F.; CAGNON, J.A. Desenvolvimento e avaliação de desempenho de um sistema de posicionamento automático para painéis fotovoltaicos. Energia na Agricultura, Botucatu, v.25, n.2, 2010, p.1-19. Disponível em: 〈http://200.145.140.50/index.php/energia/article/viewFile/52/34>. Acesso em: 1 jun. 2012.

ARENALES, S.; DAREZZO, A. Cálculo numérico: aprendizagem com apoio de software. São Paulo: Editora Tomson Learning, 2008.

CASTRO, R.M.G. Introdução à energia fotovoltaica. ed. 2.2. Lisboa: Universidade Técnica de Lisboa, Instituto Superior Técnico - DEEC/Secção de Energia, Energias Renováveis e Produção Descentralizada, 2008. 
CBSOLAR. Centro Brasileiro para Desenvolvimento da Energia Solar Fotovoltaica. Porto Alegre: Faculdade de Física PUC-RS. Disponível em: <http://www.pucrs.br/cbsolar/ntsolar/index.htm>. Acesso em: 1 jun. 2012.

CELIK, A.N.; ACIKGOZ, N. Modelling and experimental verification of the operating current of mono-crystalline photovoltaic modules using four- and five-parameter models, Applied Energy, London, v.84, n.1, p.1-15, jan. 2007. Disponível em: <http://www.sciencedirect.com/science/article/pii/S0306261906000511〉. Acesso em: 1 jun. 2012. CRESESB/CEPEL. Centro de Referência para Energia Solar e Eólica Sérgio de Salvo Brito/Centro de Pesquisas de Energia Elétrica. Energia Solar - princípios e aplicações, 2009. Disponível em: <http://www.cresesb.cepel.br/tutorial/tutorial_solar.pdf>. Acesso em: 1 jun. 2012.

FRAGA, J.R.C.P. Análise do comportamento da bateria utilizada em sistemas fotovoltaicos de pequeno porte. 2009. 137 f. Tese (Doutorado em Energia na Agricultura) - Faculdade de Ciências Agronômicas, Botucatu, 2009.

GABRIEL FILHO, L.R.A. Análise e modelagem geométrica da potência gerada por um sistema híbrido solar fotovoltaico eólico. 2007. 136 f. Tese (Doutorado em Agronomia) - Faculdade de Ciências Agronômicas, Universidade Estadual Paulista, Botucatu, 2007.

GABRIEL FILHO, L.R.A.; CREMASCO, C.P.; SERAPHIM, O.J. Análise diferencial da potência máxima gerada por um sistema solar fotovoltaico. Energia na Agricultura, Botucatu, v.25, n.2, 2010. Disponível em: 〈http://200.145.140.50/index.php/energia/article/view/60〉. Acesso em: 1 jun. 2012.

GABRIEL FILHO, L.R.A.; CREMASCO, C.P.; SERAPHIM, O.J.; CANEPPELE, F.L.

Caracterização analítica e geométrica da metodologia geral de determinação de distribuições de Weibull para o regime eólico e suas aplicações. Engenharia Agrícola, Jaboticabal, v.31, n.1, 2011. Disponível em: <http://www.scielo.br/scielo.php?script=sci_arttext\&pid=S010069162011000100006\&lng=en\&nrm=iso $>$. Acesso em: 1 jun. 2012.

GABRIEL FILHO, L.R.A.; PEREIRA, D.F.; BARATO, F.F.; MAGALHÃES, M.M. Method of numerical correction of errors occasioned by delay of records during the monitoring of environmental variables of interest for animal production. Engenharia Agrícola, Jaboticabal, v.31, n.5, 2011. Disponível em: <http://www.scielo.br/scielo.php?script=sci_arttext\&pid=S010069162011000500001\&lng=en\&nrm=iso>. Acesso em: 1 jun. 2012.

GABRIEL FILHO, L.R.A.; CREMASCO, C.P.; PUTTI, F.F.; CHACUR, M.G.M. Application of fuzzy logic for the evaluation of livestock slaughtering. Engenharia Agrícola, Jaboticabal, v.31, n.4, 2011. Disponível em: <http://www.scielo.br/scielo.php?script=sci_arttext\&pid=S010069162011000400019\&lng=pt\&nrm=iso $>$. Acesso em: 1 jun. 2012.

LORENZO, E. Eletricidade solar: ingenieria de los sistemas fotovoltaicos. Madrid: Artes Gráficas Galas, 1994. 338 p.

MACIEL, N F.; LOPES, J.D.S.; LIMA, F.Z. Energia solar para o meio rural: fornecimento de eletricidade. Viçosa: CPT, 2008. 254 p.

MARINI, J.A.; ROSSI, L.A. Sistematização do dimensionamento técnico e econômico de sistemas fotovoltaicos isolados por meio de programa computacional. Engenharia Agrícola, Jaboticabal, v.25, n.1, 2005. Disponível em: <http://www.scielo.br/scielo.php?script=sci_arttext\&pid=S010069162005000100008\&lng=en\&nrm=iso>. Acesso em: 1 jun. 2012.

PARIDA, B.; INIYAN, S.; GOIC, R. A review of solar photovoltaic technologies. Renewable and Sustainable Energy Reviews, v.15, n.3, 2011. Disponível em:

<http://www.sciencedirect.com/science/article/pii/S1364032110004016>. Acesso em: 1 jun. 2012.

PEREIRA, D.F.; BIGHI, C.A.; GABRIEL FILHO, L.R.A.; CREMASCO, C.P.C. Sistema fuzzy para estimativa do bem-estar de matrizes pesadas. Engenharia Agrícola, Jaboticabal, v.28, n.4, 2008. Disponível em: <http://www.scielo.br/scielo.php?script=sci_arttext\&pid=S0100-

$69162008000400002 \& \operatorname{lng}=$ pt\&nrm=iso $>$. Acesso em: 1 jun. 2012. 